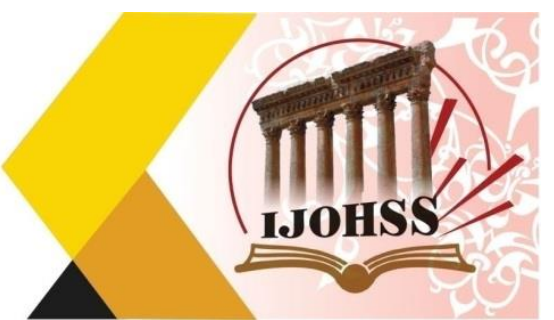

\title{
Metacognition and Language Learning
}

\author{
Assist. Lect. Nagham Oudah Alhamdawee \\ Department of English Language \\ College of education for Women- AL-Iraqia University- Iraq \\ Email: eeye93@gmail.com \\ Assist. Lect. Israa Sabeeh Abbas \\ Department of English Language \\ College of Education for Women- AL-Iraqia University- Iraq \\ Email: israa.sabeh@gmail.com
}

\begin{abstract}
The important role of teachers in any part in the world is to teach students how to learn everything around them on their own. The students must learn, how to learn and know how they have learned, and learn how to direct their learning process in the future. This concept known as metacognition, it means "thinking about one's own thinking".

Metacognition relates to language learning and teaching, it plays a central role in successful learning. The purpose of this research is to identify metacognition in the form of language learning strategies. The study discusses useful strategies and learning styles used by learners of English Language as a second language, In order to achieve the aims of this study and to assess its hypotheses the researcher collected sample of writings written by undergraduate and postgraduate level students in the department of English Language/Al-Iraqia university talking about how they learned different skills of learning English specially listening and speaking skills in English language learning classrooms, which help the student, become self-directed learners. The purpose of collecting these samples is to show how much these students know about language learning strategies, and how can they apply these strategies during their learning the English language.
\end{abstract}

Keywords: metacognitive knowledge, language learning strategies, self-directed learners. 


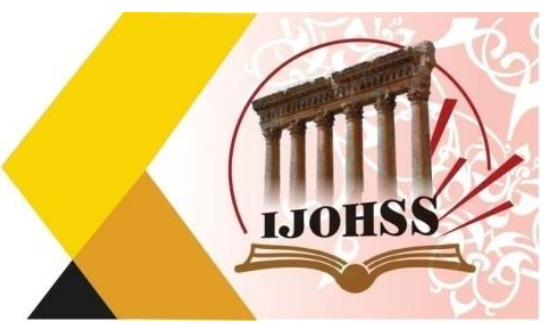

\subsection{Introduction}

The first article which announced the birth of language learner strategy research was "What the 'Good Language Learner' Can Teach U's 'by Joan Rubin in 1975, she mentioned the techniques and approaches employed by successful language learners (Cohen $\&$ Macaro (ed. 2007. P.11) which were:

1. Clarification and verifications.

2. Mentoring.

3. Memorization

4. Guessing.

5. Deductive reasoning.

6. Practice.

7. Creates opportunities for practice.

8. Production tasks related to communication. ( Rubin, 1975: 124-125)

Since then experts in learning have focused on the subject of developing new strategies for learning, and self-directed opportunities of the learners. They have researched new ways or methods, to help the learners become more aware about their metacognitive process during learning.

Metacognitive knowledge is information that the learner consults, when thinking about a particular way of thinking, or "an appreciation of what one already knows, together with a correct apprehension of the learning task and what knowledge and skills it requires, combined with the ability to make correct inferences about how to apply one's strategic knowledge to a particular situation" (Peirce,2003,p.2).

This knowledge can include information about the task, and about the learners' ability to perform that task, or about the strategies that he might use to perform that task. The basic purpose of these strategies is to make learning process easier, faster, more enjoyable, more self-directed, and effective (Oxford, 1990).

There are many methods proposed talking about the best ways to teach students a second language in the classroom practice; these include listening, speaking, reading and writing. Our focus in this paper will be on the use of the skills of listening, speaking, reading and writing by the learners.

\subsection{Literature review}

Metacognitive knowledge means, "What students know about themselves and about the tasks they accomplish and their learning strategies, which is essential for selfdirected learning" (Cotteralland Murray, 2009, p34). While Flavell (1976, p232) and Wenden (1998) defined metacognitive knowledge as "knowledge concerning one's own cognitive processes and procedures or anything related to them". Wenden (1998) identified three kinds of metacognitive knowledge: 1- Person knowledge, which means "the knowledge of learner about himself or herself as a cognitive process". It may contain the following categories (age, motivation, proficiency, effectiveness). 2-Task knowledge 


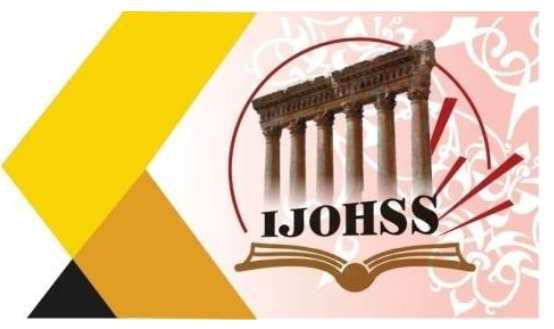

"knowledge which the learner has concerning information and resources they need to understand and accomplish a specific task" li1.ke (Task purpose, how to solve a particular task, distinguish between different tasks). 3-Strategy Knowledge concerns the knowledge of the strategies that the learner shall follow to achieve his goals and accomplish his or her task" (Cotterall and Murray (2009). P.35). Strategic knowledge may contain the following categories: general knowledge, usefulness of the strategies, etc......Role of the teacher is important also because he / she must support his/ her learners during the process of learning. "Teachers must encourage learners independence, which may be achieved through assisting learners to develop a capacity for self- reflection both on themselves as learners and on their position within society and the community".(Naznen,2009). Teachers must try to use metacognitive strategies in everyday classroom activities. They may help the students know themselves and their learning styles as a first step. They should also be prepared to do a variety of classroom activities, which will be suitable for the students as a whole.

\subsection{Learner strategies}

Rubin (1975, p43) identifies strategies as "the techniques or devices which a learner may use to acquire knowledge" (Q in Griffiths and Oxford 2014). While Oxford (1990, p8) presented another definition of language learning strategies as "Specific actions taken by the learner to make learning easier, faster, enjoyable". The simplest definition that touches the heart of language learning strategy is the definition presented by Griffiths (2008. 2013) which is "activities consciously chosen by learners for the purpose of regulating their own language learning". Oxford (1990) identifies six types of language learning strategies or kinds for strategy knowledge, which are important for any learner in the world of a second language, these strategies, include (Memory strategies) which help students to store information,(Cognitive strategies) which enable learners to understand and produce new language, (Compensation strategies) which allow learners to communicate despite deficiencies in their language knowledge, (Metacognitive strategies) which allow learners to control their own learning through organizing, planning, evaluating, (Affective strategies) which help learners gain control over their emotions, attitudes, motivations, and values and (Social strategies) which help learners to communicate with others, which include asking questions, cooperating with other learners, empathizing with others like developing cultural understanding. (Richards and Lockhart, 2000).

\subsection{Research questions}

In this research, we will try to answer the following questions:

1- What evidence of personal knowledge has the students show in the data?

2- What evidence of task knowledge has the students show in the data?

3- What evidence of strategic knowledge has the students show in the data? 


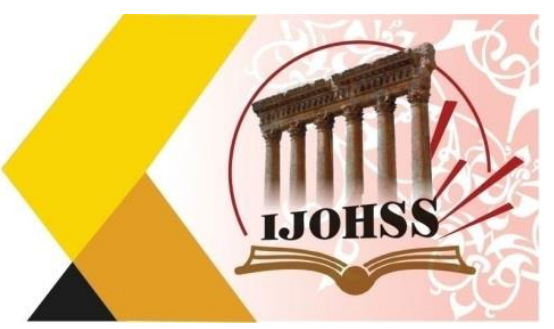

\subsection{Methodology}

In this research, there are eight narratives for undergraduate graduate students' Iraqi students, talking about their experiments in how they leaned second language and how they can develop their abilities in the four skills (listening, reading, writing and speaking). The researcher used a qualitative research methodology to analysis the stories presented here. The value of these narratives is to understand learners' strategies.

\subsection{Participants}

The participants were eight students in the department of English language department/ Al Iraqia University. The students, asked by their teacher to write a report on their academic writing and their abilities in academic writing and how can they improve their abilities on academic writing. The report was of 350 words. My focus will be on studying how learners use the strategy of (person, task, and strategic strategy and how they apply them on their writings. Which one is the most effected on the learner, and which one is the most used? Categories for person, task and strategic knowledge.

\subsection{Discussion and results}

In this research, the focus will be on studying how learners use the strategy of (person, task, and strategic strategy and how they apply them on their writings. Which ones the most effected on the learner, and which one is the most used.

Results concerning strategy use, show that the participants used different types of metacognitive strategies concerning: person, task, and strategic strategies, which reflect students' understanding of themselves as learners, as table (1) shows : It shows that learners used $45 \%$ of their writings depending on their personal knowledge, and $22 \%$ task knowledge, strategy knowledge is the less one $14 \%$ only.

Categories for person, task and strategic knowledge (Wenden, 1998)

\begin{tabular}{|l|l|}
\hline Category & Line \\
\hline 1. Person knowledge & \\
\hline a. human factors that facilitate or inhibit learning & $\mathrm{S} 1.1,3,4$. \\
\hline b. age, language aptitude, motivation, memory & \\
\hline $\begin{array}{l}\text { c. specific knowledge about how the above factors apply in the experience } \\
\text { of a learner }\end{array}$ & \\
\hline $\begin{array}{l}\text { d. knowledge about their proficiency, how well they read, write, how much } \\
\text { grammar they know }\end{array}$ & $\begin{array}{l}\text { Student } \\
1.1,2\end{array}$ \\
\hline e. what learners believe about their effectiveness as learners & $1,4,5$ \\
\hline $\begin{array}{l}\text { f. ability to mobilize and manage the resources necessary to leam and to } \\
\text { sustain the effort }\end{array}$ & \\
\hline $\begin{array}{l}\text { g. ability to achieve specific learning goals, such as writing in a second } \\
\text { language }\end{array}$ & \\
\hline 2. Task knowledge & \\
\hline
\end{tabular}




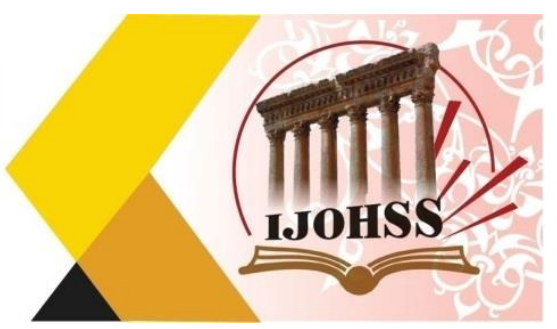

\begin{tabular}{|l|l|}
\hline $\begin{array}{l}\text { a. what learners know about the purpose of a task and how it will serve } \\
\text { their language learning needs }\end{array}$ & \\
\hline $\begin{array}{l}\text { b. knowledge that there are different requirements for different types of } \\
\text { task, for example understanding that learning to read is different from } \\
\text { learning to write or being able to distinguish a creative thinking task from a } \\
\text { problem solving task }\end{array}$ & $3,4,5$ \\
\hline $\begin{array}{l}\text { c. information about a task's demands, how to learn in general, how to go } \\
\text { about doing a particular task, and the knowledge and skills needed }\end{array}$ & $\begin{array}{l}\text { Student } \\
1.5,6 .\end{array}$ \\
\hline $\begin{array}{l}\text { d. Task knowledge is not domain knowledge, for example knowledge of } \\
\text { grammar or vocabulary }\end{array}$ & \\
\hline & \\
\hline 3. Strategy knowledge & Student \\
\hline a. general knowledge about what strategies are & $1.7,8,9$. \\
\hline b. why strategies are useful & $1,4,6$ \\
\hline c. specific knowledge about when and how to use them & $1,2,3,4$ \\
\hline d. what learners do to help themselves learn & \\
\hline
\end{tabular}

\subsection{Results}

The results show that the students had a very low attitude towards using Strategic knowledge strategy during the process of learning. We see also, how the learners are talking about their knowledge in learning the language, how they are good in some skills and weak in others. Their knowledge in the four skills (speaking, writing, reading, and listening) are varying, they are good in some skills, and bad in the other. It shows that the learners have confident in their ability to learn and they were selfreliant. They have also the motivation and enthusiastic to learn English language.

They are also aware of why she/he wants to learn, unafraid of making mistakes, unafraid of what she/he does not know, a good risk taker probably positive in his/her attitude to English language and culture.

They were also prepared to look for opportunities to encounter the language and willing to assume certain responsibility for her/his own learning. (Hedge.2000: p82). Nevertheless, the problem is that they do not know how to arrange their style to learn, and overcome their weakness in grammar, vocabulary, pronunciation...etc., and here comes the role of the teacher, he must teach them, how to arrange their thoughts, and give the learners the opportunity to exercise their metacognitive skills to reach the ultimate objective of metacognitive training.

The learners have some knowledge of task knowledge and probably a very weak knowledge about strategic knowledge because only (6) of the (8) learners used some aspects of strategic knowledge in their writings. There a lot of grammatical mistakes and wrong spelling words. There is a weak aspect in teaching those learners, because they did not study or learn anything about how to arrange their way of learning the second language. Therefore, I have some recommendations to strengthen the learner's 


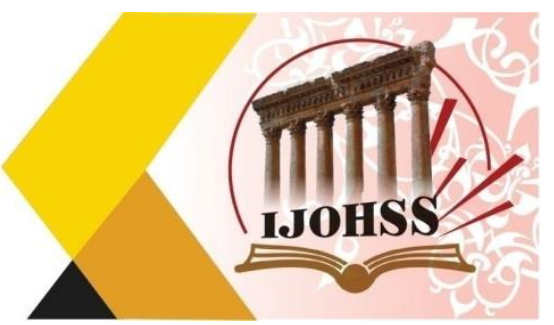

awareness of language learning strategies and help them to apply them during the learning process.

\subsection{Recommendations:}

In order to develop learners' metacognitive knowledge, and make them perfect:

1- Teachers must provide direct instructions to the learners about learning strategies to develop learner's metacognitive skills.

2- Teaching the learners learning styles, will help students identify their strengths and weaknesses in the learning experience, because in many times, students have an idea of their preferences, but do not know how to translate this information into practical activities, which will help them in their learning experience. (OZ,2005). 3- There must be ongoing training during the course of a year to teach learner of English language, about metacognitive strategies, and ,how and when to use them. 4-Teacher education programs should involve the study of metacognitive awareness to apply their knowledge on metacognition when teaching the learners.

5- They need to improve their grammar and vocabulary a, which can be achieves the explicit instruction. 6- Teachers of English language should teach learners, and encourage them, to learn the four skills: listening, reading, writing, speaking because we cannot separate learning one skill from the other three

.7- As there is a focus on teaching grammar, vocabulary, spelling and pronunciation; teachers must teach them about punctuations marks.

8- If it possible, teachers may make one class every week, to teach his students about metacognitive strategies

\section{Conclusion}

Language learning strategies are an important aspect in English language classrooms. Teaching ESL students the metacognitive strategies is an important skill, which will help students to become more self- directed learners. The role of teachers of English language is to help their students to learn "How to learn". Teachers must encourage their students to use metacognitive strategies in their learning. We cannot separate learning the skills of (listening, reading, writing, and speaking) from each other, because learning one skills connected with learning the others. Teachers have to encourage their students to act, according to what they beliefs, attitudes and values. Learners must engage in ongoing process in learning to develop their metacognitive knowledge strategies.

\section{References}

1- Adrian, Nazneen. (2009). Metacognition and language learning.

2- Cohen D. Andrew \& Macaro, Ernesto (Ed.). (2007). Language Learner Strategies.

3- Cotterall, S., \& Murray, G. (2009). Enhancing metacognitive knowledge: Structure, affordances and self. System 37(1). 


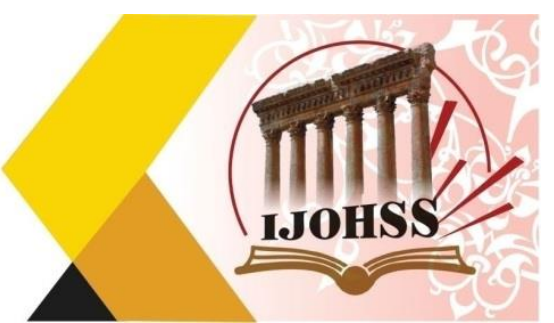

4- Flavell, J. H. (1979). Metacognition and cognitive monitoring: A new area of cognitive-developmental inquiry. American Psychologist, 34(10), 906-911.

5- Hedge, Tricia. (2000). "Education and learning in the language classroom". Oxford University press.

6- Huseyin, OZ. (2005). "metacognition in foreign/second language learning and teaching" . (H.U. Journal of Education)

7- Livingston, Jennifer A. (1997). " Metacognition: An Overview" Oxford, R. L., (1990). Language learning strategies: what every Teacher should know. Boston, Mass.: Heinle \& Heinle.

8- Pierce, W. (2003)." Metacognition: Study strategies, monitoring, and motivation". A workshop paper presented at Prince George's Community College.

9- Richards C. Jack \& Lockhart, Charles. (2000). "Reflective teaching in second language classrooms". Cambridge university press.

10- Wenden, Anita. (1998). "Metacognitive Knowledge and language learning". Oxford University Press.

\section{Appendixe (1) \\ The (8) stories of the students in full: \\ Sample (1)}

1. When it comes my speaking, I didn't know anything about methods of speaking at the beginning of the year, but now I know them.

2. I couldn't say I 'm speaking very well but I try to speak accurately about not only grammar but also true vocabulary.

3. Last term I had told what I wanted to do about my speaking, I tried to speak my friends and I thought it was very helpful to me

4. However, as you know because of my pregnancy I couldn't finish the term effectively.

5- I have some plans for the summer. One of them is that I'm going to read English Classics (at least four books) that I bought this term.

6-The other, I'm going to speak my friends who know speaking English.

7- This year I could only listen idioms that you suggested us that I downloaded from "the English we speak" in the site of bbc while I was coming to university by bus

.8- And if I had an opportunity I tried to listen some parts that had their transcription but I don't think I succeeded it

.9- Determinedly I'm going to listen them and other sites about listening.

10. Finally, you tried to improve our English so I really thank you that you have done everything for us. I'll do my best to improve myself.

Sample (2)

1. I am Elif Alyakut. I can send right now my report because of the problem of my netbook.

2. I am so sorry to get the report in deadline.

3. Firstly I want to write about my speaking. I think to have B2 level English.

4. But sometimes, I can't reflect it. Because of excited, nervous etc. 


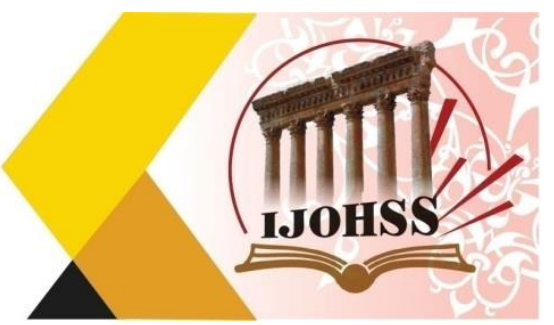

5. When I prepare the topic, everything is OK. Even I do not be nervous.

6. Also, when I talk to my friends, they must be better than me. Because I should learn new things.

7. It is not valid for speaking exam. Because It is too important being same level each other in exam.

8. I am sure that. Last term, I could not anything in mi term exam because of my partner, she was so good at talking

9. I would not say something. On the other hand, in final exam, I overcame that situation

10. Besides, I guess, I can easily express myself by writing.

11. This summer, I plan to work somewhere like airport and hotel.

12. Because I must improve myself until next term.

13. I am a student ELL, so I must be good at talking English.

14. About my listening, this was so difficult for me in prep class. And I did not be dislike. So I could not study. 15. But in this term, I always watch films and movies.

16. Especially, I write the reports about watching films and movies. I cannot easily understand firstly

17. How it can be improved? Actually, there was no other way watching films.

18. Next year I believe that I will be better than this year.

Sample (3)

19. Speaking and listening are very important for a study English Language and Literature.

20. When you graduate your department you have to know everything connected with your department such as literature, writing, speaking and listening.

21. And you know that I am going to talk about my listening and my speaking.

22. Firstly, I am telling to you my speaking. I believe that 'if you do not speak, you cannot improve, you will forget."

23. When I do not speak frequently I can forgive, I do not know what I am saying.

24. Anyway, I must tell my speaking. Actually I can speak about lots of thing such as books, music, and diary event sets.

25. But at exams I cannot do this. For instance, when I come out your room, I regret ever more.

26. Why I did tell this too?, Why I did remember this word? I guess I am exciting at exams.

27. And now I want to tell my fluency. Sometimes, when I know what I will say and something about topic I am able to speak fluently.

28. Generally, these topics are simple. I want to go by my fluency at exams.

29. You know too that I cannot do this. I say '1111' at all times. As I refer previously, I dare say, I am exciting and I cannot think

30. And I am aware of this that the more I speak the more my speaking will be fluency 31.. So, how do I improve my speaking? What are my plans?

32. I have to get around to speaking in English at public lecture, among my classmates. 


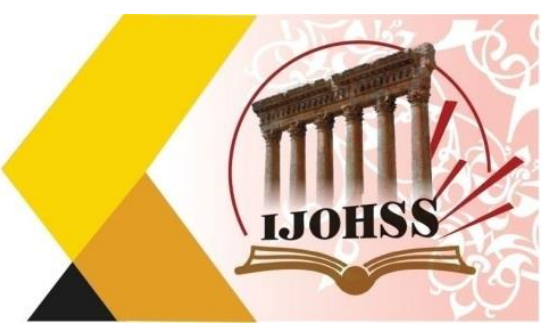

33. I should care not speaking in Turkish. Maybe I will work a place which spoken English, in this way I have to account for speaking English.

34. And I Project to go abroad with Erasmus, Mevlana or something else. For example I yearn to wander Europe countries with the train which is my utmost imagination. 35. Secondly, I want to tell my listening. I will not complain as before

36. Because my listening and my understanding is bitter than my speaking.

37 . When you or somebody else say or ask me a something I can discover easily.

38. I guess, this emanate owing to the fact that I watch foreign series and listen foreign music commonly.

39. And again same question, How do I improve my listening and my understanding?

40. I can make after much more foreign things such as film, series etc. Or something else,

41. I should do listening activities on the internet. 42. Consequently, that is my speaking and my listening. I hope that I can explain clearly.

43.And I want to thank you for helping to me or us.

Sample (4)

44. I am writing my final report that you requested. Before I start I d like to thank you for your support about my own private matters and for my improvement.

45. I enjoyed all the lessons we went through and also amazed with you different teaching technics.

46. I believe my speaking well improved since I started studying the material that you provided in the class.

47. Especially after receiving self-assessment chart and speaking skills targets list.

48. It was very helpful since I had no idea how our lecturer was assessing our speaking before that.

49. I believe that I can speak fluently and spontaneously without making any pause when I $\mathrm{m}$ interacting with others.

50. For instance when you send us the exam record I realized how effective I was on doing it while I was speaking with my partner.

51. I can use language to take part in discussion for expressing or giving my opinion about it.

52. Again I'd give my exam as an example. I and Hasan were set to discuss about picture for provided us and I express my opinion to my partner.

53. Another one was with Meric and we were discussion about improving our speaking I gave example about my way and try to persuade him. 


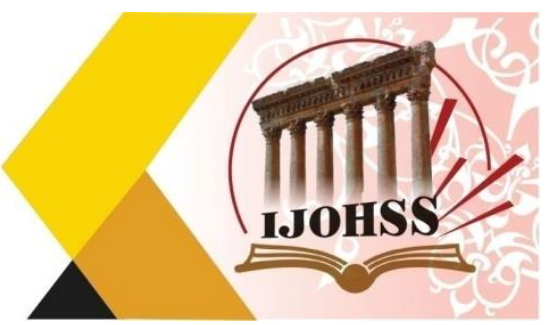

54. Watching two example videos like; Jihun and Estelle`s/ Evgheny and Dega `s help me torealized differences between the speaking levels

55. One of my main problem was at the start of the year that keeping the most of the expression in my mind to use the moment that I m speaking.

56. Writing certainly did helped to achieve what I wanted to do and also having conversation with Phd`s ,Erasmus students was another great opportunity for me.

57. Watch a lot of documentaries, received emails from English central website (every week they send you an email about that week`s topic) and followed them help me to practice.

58. I had difficulties with grammar while I was speaking

59. at least now most of the time I'm correcting myself as soon as I realized.

60. At the start of the year I mentioned about my speaking in unprofessional way but now at least I know how to asses myself.

61. I know where I'm standing right now and looking forward to taking step forward to be level that I should be which is $\mathrm{C} 1$ level.

62. Being able to use language; effectively, fluently, accurately to speak freely on professional or academic topics. I'd like to meet $\mathrm{C} 1$ level`s requirements for practice a lot.

63. As my listening; I watch TV series, talk shows, films, news, documentaries (www.ted.com), listen to the audio books (www.booksshouldbefree.com) and understand without too much effort.

64. However sometime I find difficulty understand if the speaker has strong accent that is unclear and spoken fast.

65. I should listen in range of different accent in order to be able to understand what is spoken.

66. I d like to have your feedback about how to improve my level of understanding if it's not trouble to you.

\section{Sample (5):}

67. When I first started school my speaking was very bad.

68. I could not tell my decisions' and my opinions.

69. For example teacher asked to me a question, I knew question's answer but I could not answer to teacher because of my excited.

70. It might be my shyness. Because my speaking was not enough for doing this. 


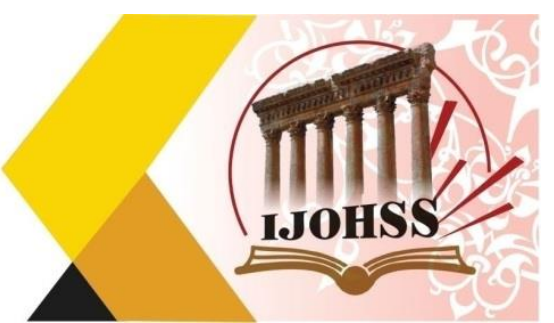

71. I believe that I manage to improve my speaking in last year, specially this year.

72. Secondly, I want to talk about what can I say and how I say. I can use basic daily English.

73. I can express myself, I can comment about my familiar topics.

74. But when I speak about something, I have fear of my mistakes.

75. Because of that I make grammatical mistakes and I forget some necessary words.

76. I cannot speak fluently. Because I always think grammar rules when I make a sentence. This effects my fluency in bad way.

77. Next, in order to do better my speaking, I always practice with my friends, I sing to English songs.

78. I have some aims for improving my speaking. One of them is going to abroad because if I go to abroad I should always use English. It helps me to improving speaking.

79. Then, I want to talk about my listening. I believe that my listening is such a good level.

80. I can easily understand what teachers and my friends says. I can understand film's dialog not at all, but majority. I can understand big part of songs.

81. My listening skill developed due to the fact that I always watch the TV series and films this year.

82. Lastly, I am going to go on watch the TV series and I am going to go on news at radio. .My listening level going to develop this way.

83. Listening is very important thing in my future life so I want to develop my listening level. If I will go to abroad, my listening will be useful to me.

\section{Sample (6):}

84. The abilities of communicating fluently in English is very important. Therefore, it is necessary to improve these two skills: listening and speaking.

85. And I think my listening and speaking skills improve.

86. Progressing in my speaking and listening skills requires that I pay attention to way my communicate with my friends, family members. When I become conscious of the way

87. If it needs to talk about my listening; Listening is enjoyable but difficult range.

88. If I listen carefully, I can understand. In the beginning, when I didn't understand a word, I insisted on translating it in my mind. 


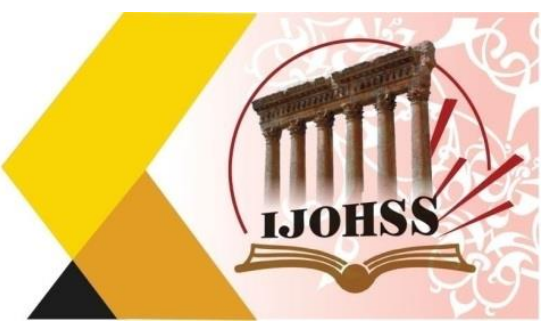

89. This approach resulted in confusion. No longer, while I'm listening to another person speaking, the temptation is to immediately translate into my language.

90. Speaking is the hardest range in English for me.

91. For speaking fluently, I have to be self-confident, listen to news or songs, read the book and newspapers, learn a new word daily, watch film etc.

92. I plan that I can go abroad such as England. I can work tourist places in summer so I can make a practice.

93. I should spend my time on studying about this topic. I must develop my speaking for being the best...

\section{Sample (7) :}

94. Firstly, when it comes my speaking, I didn't know anything about methods of speaking at the beginning of the year, but now I know them.

95. I couldn't say I 'm speaking very well but I try to speak accurately about not only grammar but also true vocabulary.

96. Last term I had told what I wanted to do about my speaking. I tried to speak my friends and I thought it was very helpful to me.

97. However, as you know because of my pregnancy I couldn't finish the term effectively.

98. I have some plans for the summer. One of them is that I'm going to read English Classics (at least four books) that I bought this term.

99. The other, I'm going to speak my friends who know speaking English.

100.+ This year I could only listen idioms that you suggested us that I downloaded from "the English we speak" in the site of BBC while I was coming to university by bus.

101. And if I had an opportunity I tried to listen some parts that had their transcription but I don't think I succeeded it.

102. Determinedly I'm going to listen them and other sites about listening.

103. Finally, you tried to improve our English so I really thank you that you have done everything for us. I'll do my best to improve myself.

Sample (8) :

104. Firstly, I want to tell about my speaking. It is very changeable it depends on situations. 


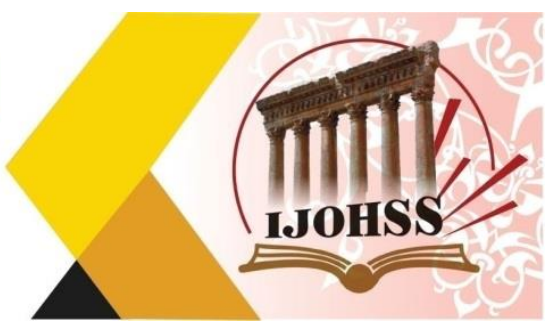

105. For example, this summer I worked somewhere and I have to speak because nobody almost not Turkish people. I can speak and it was first experience.

106. I thought I can't say anything but by and by I realized that I can speak.

107. I can deal with most situations if I want but I don't have self-confidence. So I don't know how I can deal with this.

108. I am afraid this will be always like this. I want to work somewhere this summer again. Maybe it can be a solution.

109. In high school, we just studied university exams and we did reading grammar and sometimes listening but we didn't do speaking.

110. So when I came here I couldn't speak first time. Now I am trying to speak better and am going to try to be better.

111. I watched film in high school and I will watch again.

112. Most of time I can't speak unprepared into conversation on topic anything. I force myself to speak. I hope I can succeed that.

113. And my listening is the same as speaking sometimes. I like listening music not Turkish.

114. I try translating. I think, the most important thing is subtitle film. I don't like translated film. It is usually wrong and nonsense.

115. When I watching film I can understand better but when you are speaking or anybody are speaking sometimes I can't listen and understand I don't know why.

116. It is coming to me complicated and I don't understand all of sentences you or anybody spoke.

117. Finally, I am going to try speaking and listening every day in this summer. I speak better next term.

118. In addition, I listened and read my speaking all of term and they are bad I think and you are very right..

119. Thank you for everything and your patience. 